\title{
PERANCANGAN DAN IMPLEMENTASI GOLDEN RATIO PADA DESAIN MEKANIK DAN ELEKTRIK AERO ROBOTIK
}

\section{DESIGN AND IMPLEMENTATION GOLDEN RATIO IN MECHANICAL AND ELECTRICAL DESIGN AERO ROBOTIC}

\author{
Suharmin Bahri'1, Mohamad Ramdhani ${ }^{2}$, Unang Sunarya ${ }^{3}$ \\ 1,3Prodi D3 Teknik Telekomunikasi, Fakultas Ilmu Terapan, Universitas Telkom \\ 2Prodi S1 Teknik Elektro, Fakultas Teknik Elektro, Universitas Telkom \\ ${ }^{2}$ mohamadramdhani@telkomuniveristy.co.id, ${ }^{3}$ unangsunarya@ $@$ telkomuniversity.ac.id
}

\begin{abstract}
Abstrak
Pengawasan di daerah perbatasan, pengambilan foto udara di daerah terpencil, identifikasi kerusakan pada daerah bencana yang sulit dijangkau, tentunya tugas seperti itu tidak mudah dilakukan manusia. Aero robot sebagai mobile robot yang dapat bergerak fleksibel diudara dengan kemampuan untuk menjangkau daerah yang sulit dan berbahaya tanpa harus membahayakan nyawa pilot diajukan sebagai penelitian untuk menangani permasalahan-permasalahan tersebut. Penelitian ini dibuat dengan memadukan unsur seni matematis dan teknologi dengan menerapkan teori golden ratio pada teknologi perancangan mekanik aero robot yang disebut sebagai multicopter. Hasil penelitian ini telah terealisasikan perancangan dan implementasi mekanik aero robot yang dapat dikendalikan sehingga menuju arah yang ditentukan pada ketinggian tertentu dengan hasil kualitas terbang yang baik dan sikap wahana yang stabil.
\end{abstract}

\section{Kata kunci : aero robot, golden ratio, multicopter}

\begin{abstract}
Surveillance in the border area, an aerial photo in remote areas, identification of damage to the affected areas difficult to reach, such a task would not be easy to be human. Aero robot as a mobile robot that can move flexibly in the air with the ability to reach areas that are difficult and dangerous without endangering the lives of the pilots proposed as research to address these issues. This research was made by combining elements of art and technology by applying the mathematical theory of the golden ratio in the mechanical design technology aero robot called as multicopter. The results of this research have been realized the design and implementation of an aero mechanical robot that can be controlled so that the direction specified at a certain height with the results of the flying qualities of a good and stable vehicle attitude.
\end{abstract}

Keywords: aero robot, golden ratio, multicopter

\section{PENDAHULUAN}

Aero robot semakin populer di kalangan peneliti seluruh dunia atas fleksibilitas dan kemampuan untuk melakukan berbagai tugas yang tidak bisa dilakukan manusia karena terkendala oleh bermacam-macam faktor, seperti melakukan pengawasan di daerah perbatasan, mengambil foto udara di daerah terpencil, identifikasi kerusakan daerah bencana yang sulit di jangkau dan lain- 
lain. Keuntungan dari aero robot utamanya adalah dapat menjangkau daerah yang sulit dan berbahaya tanpa membahayakan nyawa pilot.

Dalam perkembangannya, terdapat beberapa jenis aero robot yang sering kita ketahui diantaranya yaitu jenis fixed wing dan copter. Kedua jenis ini memiliki kelebihan dan kekurangannya asing-masing. UAV jenis fixed wing memiliki kecepatan dan efisiensi energi yang besar, namun manuverabilitasnya kecil sehingga sangat sulit untuk dapat melakukan hold position ditambah lagi dibutuhkan lokasi khusus untuk melakukan take off dan landing. Jenis copter dapat dikatakan memiliki efisiensi yang lebih kecil bila dibandingkan dengan jenis fixed wing karena menggunakan motor lebih banyak dan bekerja secara terus menerus, namun memiliki kelebihan dengan kemampuan vertical take off-landing (VTOL) sehingga tidak diperlukan jalur khusus untuk melakukan take off dan landing dan kemampuan melayang statis, jenis ini memiliki manuverabilitas yang baik.

Pada penelitian sebelumnya [1] tentang rancang bangun aero robot tentang sistem keseimbangan (kontrol sikap) memiliki permasalahan pada penggunaan multirotor. Salah satu masalah yang sering menjadi kendala dalam penggunaan multirotor adalah ukuran dan desain yang besar sehingga dibutuhkan ruang yang cukup besar untuk meletakkan dan menyimpan multirotor, ini berakibat kurangnya fleksibilitas untuk aero robot atau pada penelitian ini disebut multicopter.

Oleh sebab itu dalam penelitian ini dirancang desain platform multirotor yang dapat melakukan manuver dasar dengan stabil, mendesain bingkai pelindung yang dapat melindungi perangkat vital dari tabrakan atau kecelakaan saat pengujian aplikasi multicopter ini, dan mengetahui komponen dan perangkat apa saja yang dibutuhkan dalam pembuatan platform multirotor.

\section{DASAR TEORI}

\subsection{Pergerakan Dasar Multirotor}

Pada multirotor terdapat beberapa pergerakan dasar yang bertujuan untuk mengatur sikap dan posisi multirotor antara lain sebagai berikut:

\section{a. Heading/throttle}

Pergerakan ini dilakukan dengan cara menambah atau menurunkan kecepatan masing-masing motor dengan besar yang sama.

b. Roll

Pergerakan roll dilakukan dengan cara meningkatkan (atau menurunkan) kecepatan putar motor kiri dan menurunkan (atau menaikan) kecepatan putar motor kanan yang memiliki arah putar pada sumbu X.

c. Pitch

Pergerakan pitch hampir sama dengan pergerakan roll, dimana pergerakan pitch direalisasikan dengan mempercepat (atau memperlambat) putaran motor depan dan memperlambat (atau mempercepat) putaran motor belakang yang memiliki arah putar pada sumbu y.

d. Yaw

Perintah yaw direalisasikan dengan cara mempercepat (atau memperlambat) putaran motor depan dan belakang serta memperlambat (atau mempercepat) putaran motor kiri dan kanan dengan arah putar pada sumbu $\mathrm{Z}$ sebagai referensi. 


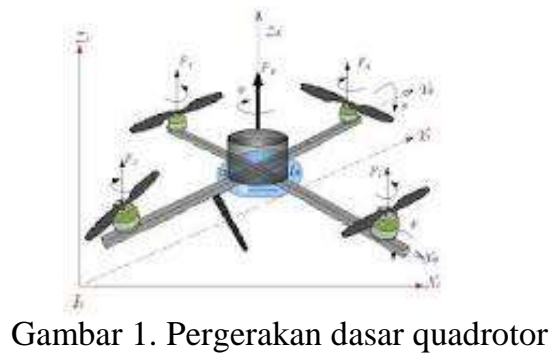

\subsection{Golden Ratio}

Golden Ratio adalah sebuah rasio/ perbandingan kompleks yang berasal dari huruf Yunani phi (Ф) menggambarkan satu set figur geometrik yang termasuk di dalamnya ; garis, segiempat, dan spiral. Figur-figur tersebut jika digambar sesuai dengan The Divine Proportion dianggap sebagai bentuk yang sempurna dan paling memuaskan secara estetis.

Golden Ratio diperoleh dari pembagian satu angka dalam deret Fibonacci dengan angka sebelumnya. Angka Fibonacci memiliki satu sifat menarik, jika kita membagi satu angka dalam deret tersebut dengan angka sebelumnya, akan didapat sebuah angka hasil pembagian yang besarnya sangat mendekati satu sama lain. Besar hasil pembagiannya mendekati satu sama lain dan bernilai tetap setelah angka ke 13 dalam deret tersebut. Sedangkan deret Fibonacci itu sendiri adalah deret yang terbentuk dengan masing-masing angka dalam deret tersebut merupakan hasil penjumlahan dari dua angka sebelumnya.

Bentuk dari deret Fibonacci itu adalah : 0, 1, 1, 2, 3, 5, 8, 13, 21, 34, 55, 89, 144, 233, $377 \ldots$ Sedangkan hasil pembagiannya, bernilai sama setelah angka ke-13 :

$$
\begin{aligned}
& 233 / 144=1,618 \\
& 377 / 233=1,618 \\
& 610 / 377=1,618 \\
& 987 / 610=1,618 . . d s t
\end{aligned}
$$

Nilai 1,618 inilah yang dikemudian dikenal dengan Golden Ratio dan kemudian dilambangkan dengan $\Phi$ (Phi).

\subsection{Tx/Rx Remote Control}

Transmitter (Tx) remote control adalah suatu perangkat pengirim sinyal radio frekuensi (RF). Transmitter akan mengirimkan sinyal RF ke receiver $(\mathrm{Rx})$. Receiver $(\mathrm{Rx})$ remote control adalah suatu perangkat penerima sinyal radio frekuensi. Transmitter dan receiver ini akan digunakan untuk mengirimkan sinyal dan mengaktifkan board controller dan gyro serta digunakan untuk mengontrol pergerakan wahana. 


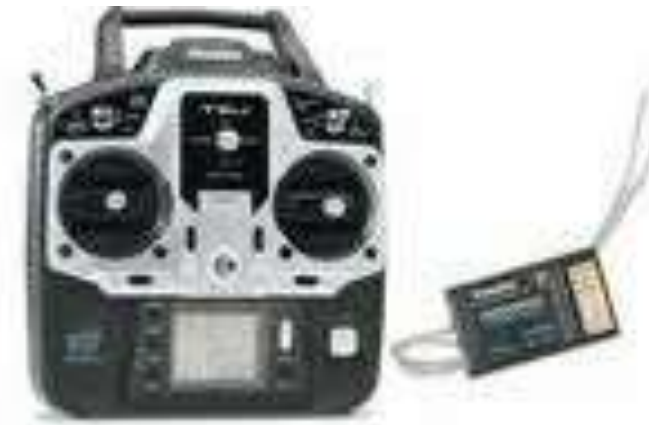

Gambar 2. Tx/Rx remote control

\subsection{Electronic Speed Controller (ESC)}

Electronic Speed Controller atau ESC merupakan sirkuit elektronik yang berfungsi untuk mengubah kecepatan, arah motor brushless dan mungkin juga untuk bertindak sebagai rem dinamis. Sebuah ESC bisa menjadi unit yang berdiri sendiri yang dihubungkan ke saluran kontrol penerima throttle atau dimasukkan ke dalam penerima itu sendiri.

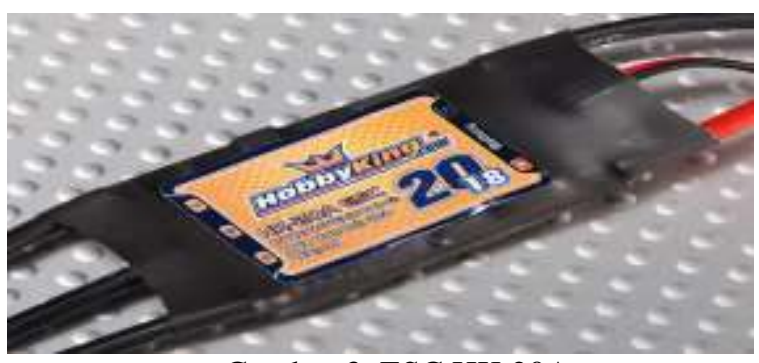

Gambar 3. ESC HK 20Amp

\subsection{Brushless DC Motor}

Brusless DC motor yang juga dikenal dengan nama electronically commutated motors (ECMs, EC motors) adalah motor elektrik sinkron yang digerakan oleh arus searah (DC) dan memiliki sistem elektronik lebih ringan bila dibandingkan dengan sistem mekanik pada commutators dan brushes. Hubungan arus ke torsi dan beda potensial ke kecepatan dari brushless DC motors adalah linear. Motor BLDC dideskripsikan dengan nama motor stepper dengan magnet yang permanen dan ditempatkan pada posisi yang tetap.

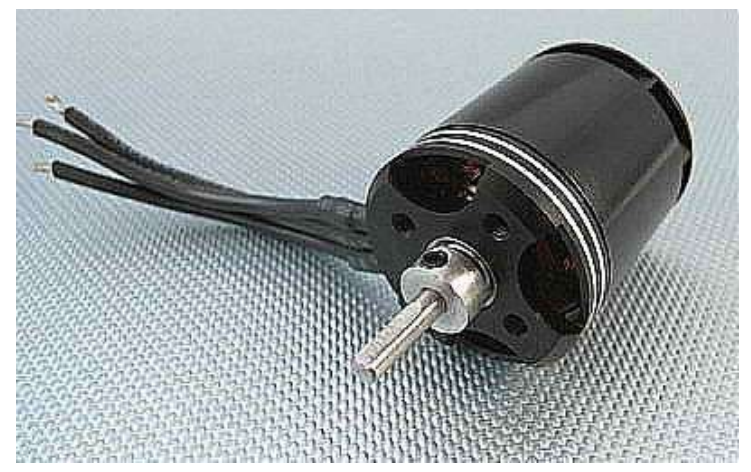

Gambar 4. Brushless motor

\subsection{Propeller}

Propeller (atau baling-baling) berfungsi untuk menjalankan pesawat terbang. Propeller memindahkan tenaga dengan mengkonversi gerakan rotasi menjadi daya dorong untuk 
menggerakkan multicopter. Hal terpenting yang berpengaruh terhadap propeller adalah kekuatan/mekanikal propertis dari propeller. Ada dua faktor yang mempengaruhi mekanikal tersebut, diantaranya adalah material propeller dan desain dari propeller itu sendiri.

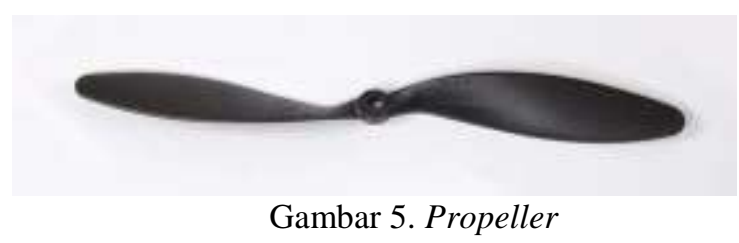

\subsection{Battery Lithium Polimer}

Catu daya yang digunakan untuk bagian penggerak digunakan catuan DC berupa battery jenis lithium polimer dengan tegangan 12,6 V dan arus $2200-4400 \mathrm{~mA}$.

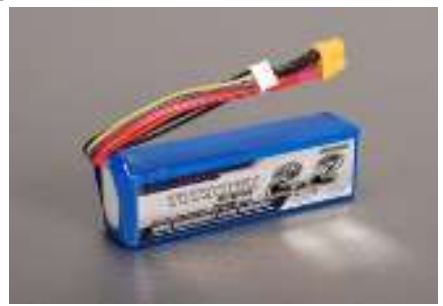

Gambar 6. Battery lithium polimer

\subsection{AutoCAD 2012}

AutoCAD adalah sebuah software atau perangkat lunak komputer CAD (Computer Aided Design) yang berguna untuk menggambar 2 dimensi dan 3 dimensi yang Dikembangkan oleh Autodesk. AutoCAD 2012 digunakan oleh insinyur sipil, land developers, arsitek, insinyur mesin, desainer interior dan lain-lain.

\section{PERANCANGAN dan REALISASI}

\subsection{Gambaran Umum Sistem}

Pada perancangan sendiri, terdapat 2 hal utama yang di fokuskan, yang pertama adalah perancangan sistem mekanik yang handal, fleksibel dan mampu di upgrade. Kedua adalah pengintegrasian sistem elektronik sehingga wahana mampu di kendalikan dan di kontrol untuk melakukan pergerakan dasar ketika terbang.

\subsection{Sistem Mekanik}

Sistem Mekanik yang akan dibuat merupakan sistem mekanik dari multirotor yang mampu di lipat dan separasikan serta mampu di di set pada mode quadcopter ataupun hexacopter sesuai dengan kebutuhan berdasarkan beratnya payload yang akan terbangkan oleh multicopter. Serta pengintegrasian komponen elektronika dan aksesoris tambahan ke sistem mekanik multirotor secara efisien dan teratur hingga tampak aerodinamis, karena cukup berpengaruh terhadap power wind dan kestabilan terhadap multirotor. Berikut ini merupakan flowchart sistem mekanik dari multicopter yang di buat: 


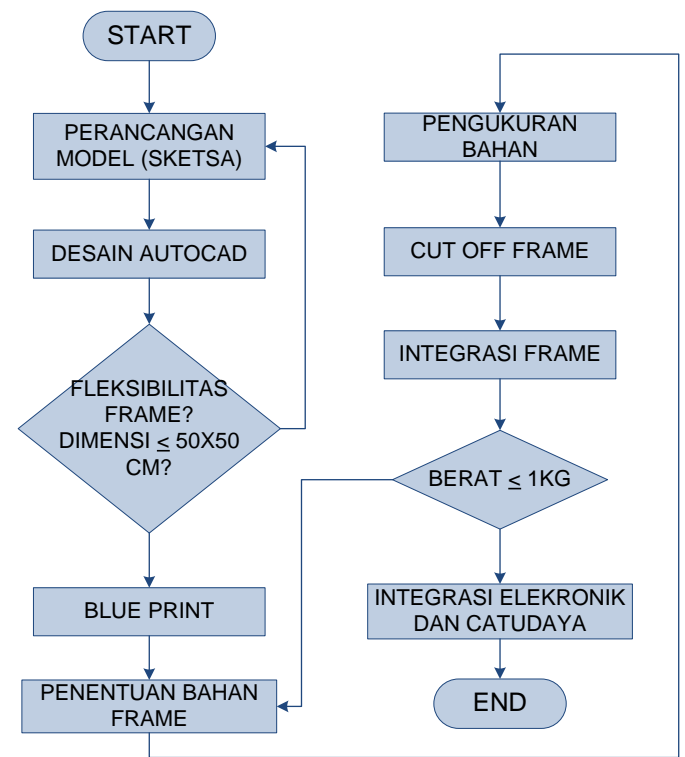

Gambar 7. Flowchart sistem mekanik

\subsection{Sistem Elektrik}

Sistem elektrik saling di integrasikan agar dapat membentuk satu kesatuan multirotor yang mampu terbang dan melakukan surveillance dengan stabil dan dapat dikontrol untuk melakukan pergerakan dasar sehingga tercipta wahana terbang yang bermanfaat baik itu untuk penelitian atau untuk pengabdian masyarakat dan komersil. Adapun gambaran umum dari sistem elektrik sebagai berikut :

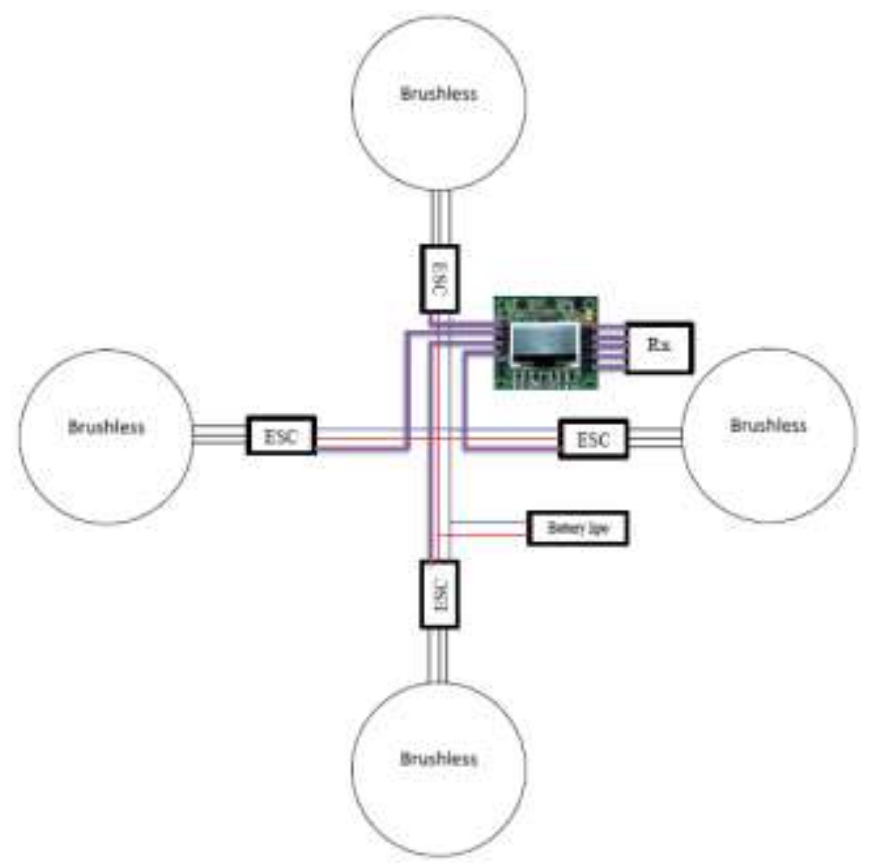

Gambar 8. Perancangan elektrik 
Adapun flowchart sistem elektrik perangkat ini adalah sebagai berikut:

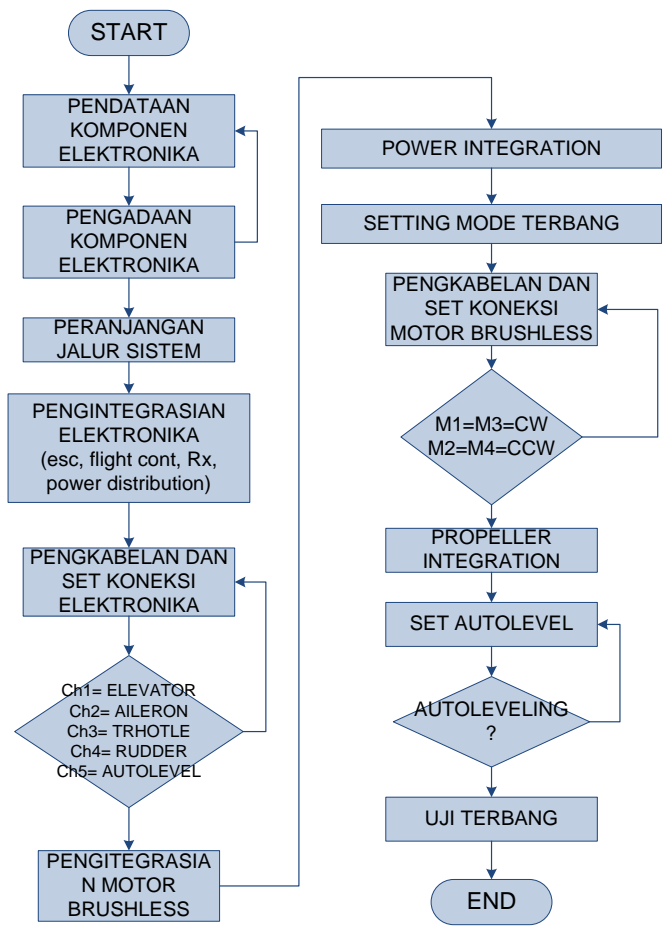

Gambar 9. Flowchart sistem elektrik

\subsection{Pemodelan Airframe Metode Golden Ratio}

Golden Ratio merupakan metode perancangan yang digunakan untuk merancang desain mekanik dan airframe dari multicopter. Metode ini di gunakan berdasarkan nilai matematis dan unsur seni yang coba dipadukan untuk memperoleh hasil yang terbaik untuk di terapkan pada penelitian ini. Adapun perancangan mekanik dan airframe adalah sebagai berikut :

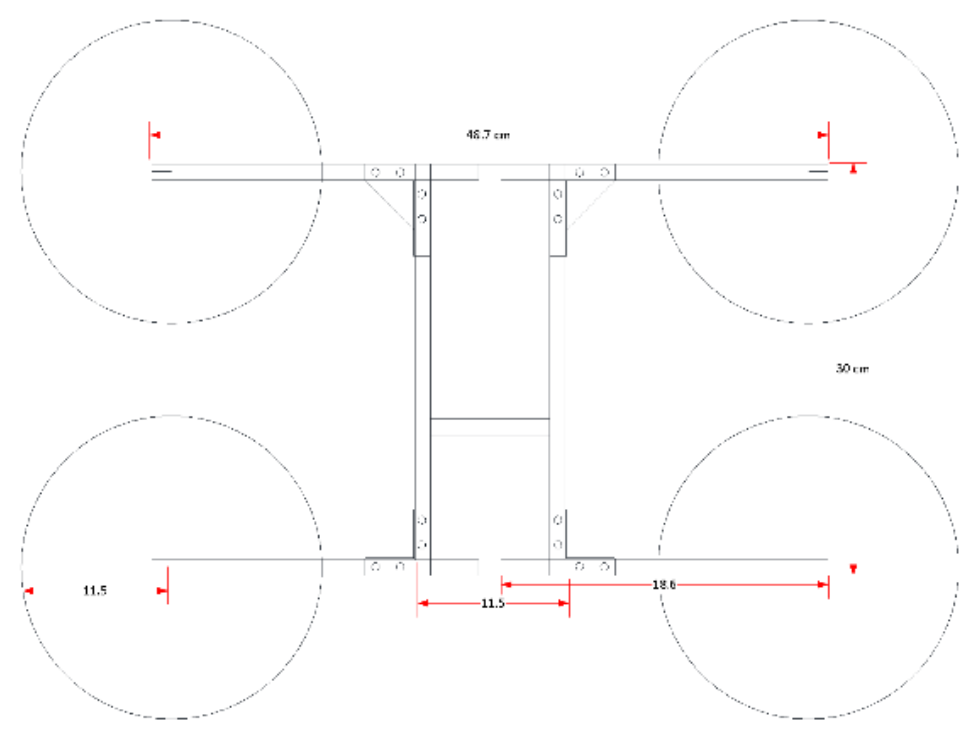

Gambar 10. Airframe full 


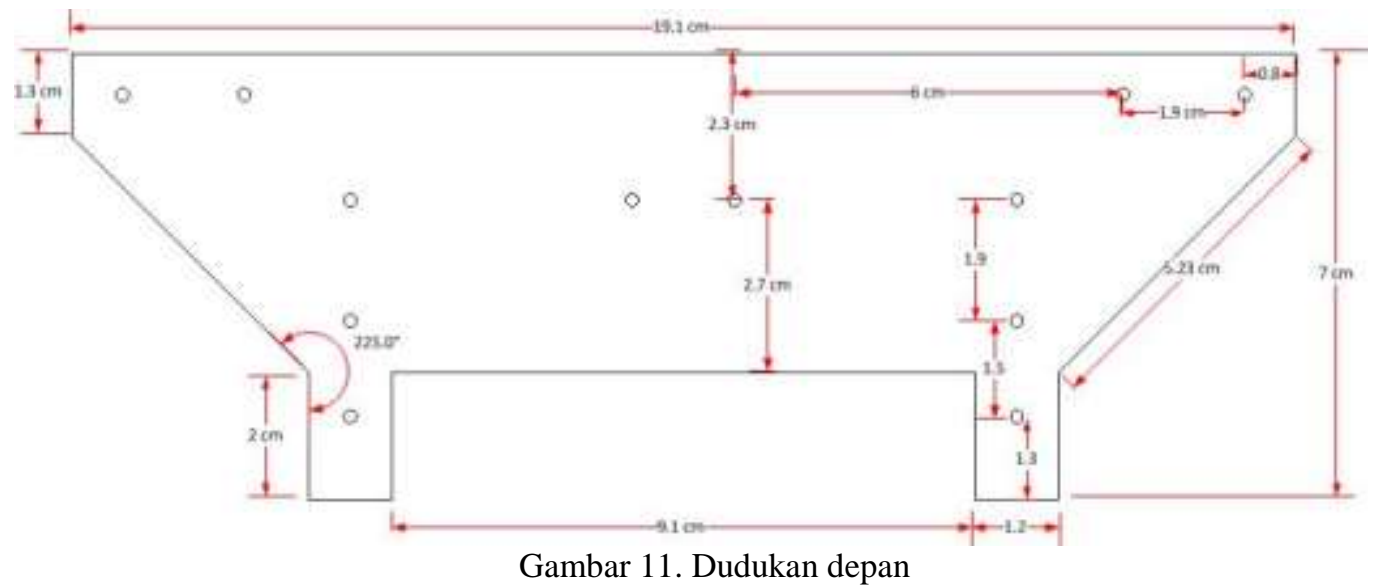

\section{PENGUJIAN}

Pada bagian ini dijelaskan bagaimana pengujian dilakukan berikut hasil yang diperoleh. Pengujian komponen dan hardware dilakukan dengan tujuan untuk mengetahui performansi dan menguji kemampuan perangkat dalam serangkaian uji coba misi. Dari beberapa skenario misi yang telah ditentukan, maka dapat dikatakan penelitian ini sesuai dengan perancangan atau belum. Pengujian yang dilakukan terdiri dari pengujian payload, pengujian remote terhadap multicopter, konsumsi baterai, ketahanan terhadap air, jenis dan ukuran propeller, kestabilan motor brushless dan kestabilan quadcopter ketika terbang.

\subsection{Pengujian Payload}

Pengujian payload bertujuan untuk mengetahui seberapa besar beban yang mampu untuk dibawa terbang. Pengujian dilakukan dengan menambahkan beban yang bervariasi. Hasil pengujian didapatkan data bahwa batas maksimal payload adalah 800 gram.

\subsection{Pengujian Remote $T x-R x$}

Pengujian remote $T x$ - $R x$ bertujuan untuk mengetahui jarak maksimal dari Tx-Rx yang digunakan dengan berbagai skenario kondisi lapangan. Pengujian ini dilakukan dengan cara membandingkan jarak maksimal yang mampu dicakup oleh remote untuk mengendalikan perangkat ini. Adapun skenarionya yaitu Skenario 1 open area, Skenario 2 Tx indoor Rx outdoor dan Skenario 3 Tx outdoor Rx outdoor dengan penghalang (gedung). Hasil pengujian didapatkan data sebagai berikut :

Dari hasil pengujian didapatkan kesimpulan bahwa kondisi lapangan dan faktor penghalang sangat berpengaruh terhadap jarak jangkauan remote $T x$ - $R x$. Sehingga kita harus memperhatikan kondisi lingkungan untuk menghindari loss control dan loss signal pada wahana ketika terbang.

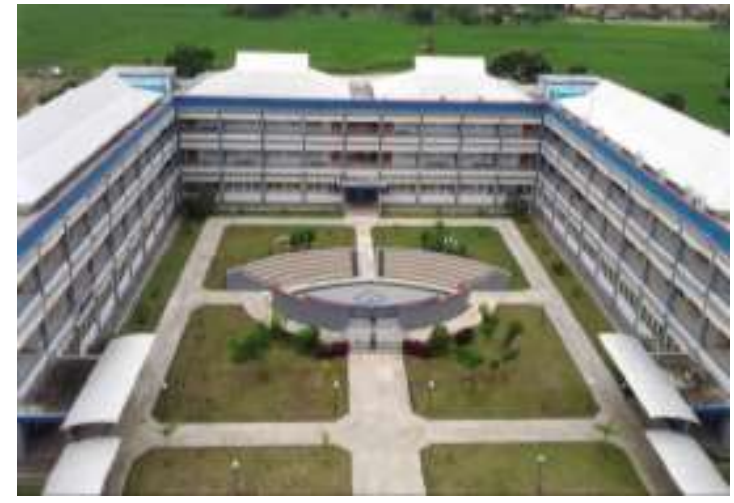

Gambar 12. Lokasi pengujian remote 


\subsection{Pengujian Battery}

Pengujian battery dilakukan dengan cara melakukan beberapa kali pengujian dan menghitung seberapa lama wahana dapat terbang dengan beberapa skenario. Adapun skenario yang dilakukan adalah sebagai berikut: Skenario 1 wahana diterbangkan tanpa beban payload dan menggunakan baterai Lithium Polymer 3 cell 11.1v, 2.2A. Skenario 2 wahana diterbangkan dengan beban payload dan menggunakan baterai Lithium Polymer 3c ell 11.1v, 2.2A.

Dari hasil pengujian didapatkan kesimpulan bahwa konsumsi battery pada wahana ketika terbang dipengaruhi juga oleh besarnya beban. Semakin besar beban yang dibawa oleh wahana maka semakin besar pula konsumsi battery.

Tabel 1. Pengujian konsumsi battery

\begin{tabular}{|c|c|c|}
\hline $\begin{array}{c}\text { Pengujian } \\
\text { ke- }\end{array}$ & Skenario 1 & Skenario 2 \\
\hline 1 & 13 menit 30 detik & 8 menit 12 detik \\
\hline 2 & 12 menit 54 detik & 6 menit 55 detik \\
\hline 3 & 12 menit 49 detik & 6 menit 40 detik \\
\hline 4 & 13 menit 12 detik & 7 menit 10 detik \\
\hline 5 & 11 menit 52 detik & 7 menit 20 detik \\
\hline 6 & 12 menit 43 detik & 6 menit 40 detik \\
\hline 7 & 11 menit 56 detik & 7 menit 4 detik \\
\hline 8 & 13 menit 45 detik & 5 menit 56 detik \\
\hline 9 & 12 menit 43 detik & 8 menit 13 detik \\
\hline 10 & 12 menit 32 detik & 7 menit 32 detik \\
\hline
\end{tabular}

\subsection{Pengujian Waterproof}

Pengujian ini bertujuan untuk mengetahui kemampuan wahana untuk menjaga komponen elektronika yang dapat rusak akibat terkena air atau ketika menghadapi kondisi hujan atau wahana mendarat pada permukaan berair. pengujian dilakukan dengan cara menerbangkan wahana dibawah guyuran hujan/ air dan mendaratkan wahana pada permukaan berair.

Dari hasil pengujian didapatkan kesimpulan bahwa wahana mampu diterbangkan pada kondisi dan lingkungan yang berair tanpa adanya kerusakan dan korsleting pada komponen elektronika. Hal ini dikarenakan aero robot telah didesain untuk tahan terhadap gangguan kerusakan yang di akibatkan oleh cairan dengan cara meletakkan komponen yang vital dan sensitif pada chasing yang dibuat khusus dengan tambahan silikon dan melapisi elektroniknya dengan lapisan epoxy.

\subsection{Pengujian Motor Brushless}

Pengujian motor brushless bertujuan untuk mengetahui apakah brushless yang digunakan stabil atau tidak. Dalam beberapa kasus banyak ditemukan brushless yang tidak stabil, hal ini dapat dilihat dari tingkat kebisingan dan getaran yang dihasilkan dari brushless. Kenyataanya ketidakstabilan dari brushless sangat berpengaruh terhadap kestabilan dari aero robot. Getaran yang besar yang dihasilkan dari brushless yang tidak stabil dapat berdampak buruk terhadap pembacaan sensor dari aero robot yang berakibat terjadinya error yang dapat merusak. 


\subsection{Pengujian Kestabilan Wahana}

Pada tahap ini perangkat diberi payload berupa kamera wireless kemudian diterbangkan dan melakukan surveillance. Dari hasil gambar/ video yang didapatkan dapat disimpulkan stabil atau tidaknya, getaran yang berlebihan menyebabkan ketidakstabilan pada wahana ketika terbang hal itu dapat berakibat sulitnya wahana untuk dikontrol oleh pilot dan ketika wahana diberi muatan berupa kamera maka kualitas gambar yang diperoleh sangatlah buruk sehingga tidak dapat melakukan surveillance dengan baik.

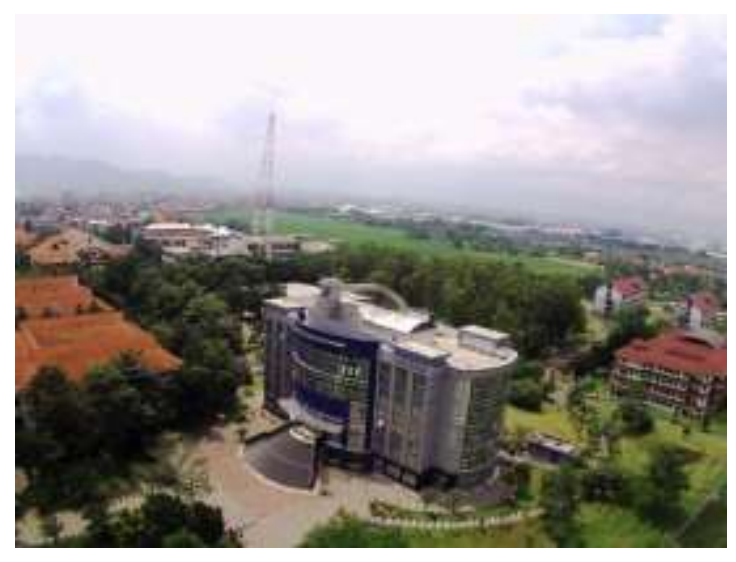

Gambar 13. Hasil gambar dari udara

Dari hasil gambar yang diperoleh maka dapat dikatakan perangkat ini dapat terbang dengan stabil, karena mampu melakukan surveillance dengan sempurna dan dapat dikendalikan sesuai dengan yang diingikan oleh pilot.

\section{KESIMPULAN}

Berdasarkan hasil perancangan dan pengujian pada penelitian ini maka dapat di ambil kesimpulkan sebagai berikut :

1. Berat maksimal payload yang mampu dibawa oleh multicopter tergantung dari berapa banyak motor yang digunakan.

2. Penggunaan Electronic Speed Controller (ESC) dan motor brushless di setiap lengan sebaiknya memiliki spesifikasi yang sama sehingga performansi wahana bisa maksimal.

3. Kondisi lapangan sangat berpengaruh terhadap jarak dan luasnya jangkauan remote terhadap multicopter.

4. Komponen elektronika yang digunakan pada multicopter rentan terhadap kerusakan yang diakibatkan oleh air, maka dibutuhkan frame dan chasing yang mampu melindungi wahana dari pengaruh langsung dari air.

5. Propeller dan motor brussless rentan terhadap kecacatan produksi yang berakibat pada ketidakstabilan wahana

\section{Daftar Pustaka:}

[1] Dwi, Ikhsan. 2012. Rancang Bangun Sistem Keseimbangan (Kontrol Sikap) Pada Aerorobotik Untuk Surveillance Dan Monitoring Berbasis Mikrokontroler. Proyek Akhir Institut Teknologi Telkom Bandung 
[2] Miguel, Jorgebrito. 2009. Quadrotor Prototype. Disertasi. Engenharia Mecanika. Lisbon

[3] Rasidi, Subagio. 2010. Aerial Photography dengan Quadrocopter. Jurnal. Austria.

[4] Sofer, Pavel Ing. 2012. "Multicopter Potentialities". Czech Republic.

[5] http://www.diydrones.com

[6] http://www.eramuslim.com/peradaban/quran-sunnah/penciptaan-allah-dan-thegolden-ratio.htm\#.UQiD7-R3TVF, tanggal diakses terakhir: 30/1/2013

[7] http://www.flitetest.com

[8] http://www.Hobbyking.com 